\title{
CARBON ISOTOPE COMPOSITION OF GRAPHITE IN MANTLE ECLOGITES.
}

\author{
Schulze $^{(1)}$, D.J.; Valley ${ }^{(2)}$, J.W.; Viljoen ${ }^{(3)}$, K.S. and Spicuzza ${ }^{(2)}, M$.
}

(1) Department of Geology, University of Toronto, Erindale College, Mississauga, Ontario, Canada; (2) Department of Geology and Geophysics, University of Wisconsin, Madison, Wisconsin, USA; (3) Anglo American Research

Laboratories, Johannesburg, South Africa.

The carbon isotopic composition of diamond is reasonably well-known from measurements on hundreds of diamonds of known paragenesis. With very few exceptions, $\delta^{13} \mathrm{C}$ values of peridotite-suite diamonds are in the restricted range -2 to $-9 \% o_{\mathrm{PDB}}$, whereas $\delta^{13} \mathrm{C}$ for eclogitic diamonds ranges from approximately +2 to $-34 \% o_{\mathrm{PDB}}$ (e.g., Sobolev et al., 1979; Deines, 1980; Harris, 1987). In contrast to this large data set, few isotopic data have been published for either eclogitic or peridotitic mantle-derived graphite. Values of $\delta^{13} \mathrm{C}$ for primary graphites from peridotite xenoliths (-4.8 to $-10.04 \%$; Kropotova and Fedorenko, 1970; Pearson et al., 1990; Schulze and Valley, in press) are similar to those from peridotitic diamonds. Existing carbon isotope data for graphite in mantle eclogites from Mir (Kropotova and Fedorenko, 1970), Roberts Victor (Deines et al., 1987), and Orapa (Deines et al., 1991) are, with one exception, in the "typical mantle range" (-3.98 to $-8.7 \%$ p $\left._{\mathrm{PDB}}\right)$. Graphite from a Schaffer, Wyoming kyanite eclogite (Schulze and Valley, in press) is unusually light, with $\delta^{13} \mathrm{C}=-14.31 \%$. An additional anomalous graphite analysis $\left(\delta^{13} \mathrm{C}\right.$ of $-20.3 \%$ ) was reported by Deines et al. (1991) for a corundum-garnet-spinel assemblage of uncertain affinity, also from Orapa. To enlarge the data base for mantle-derived graphites, we present carbon isotope data for graphites from 23 eclogite xenoliths, from the Bellsbank and Jagersfontein kimberlites in South Africa and the Orapa and Letlhakane kimberlites in Botswana.

Most of our new data (Table 1) are normally distributed about a $\delta^{13} \mathrm{C}$ value near -5 to $-6 \%$. Interesting features in this new data set include a very light value of $-12.50 \%$ o for an eclogite from Letlhakane, and the fact that 3 of the 8 Bellsbank samples have a $\delta^{13} \mathrm{C}$ value near $-2.9 \%$. These latter values are unusually heavy, relative to the strong peaks for both eclogitic and peridotitic diamonds at approximately $-6 \%$, but are similar to many of the $\delta^{13} \mathrm{C}$ values for loose diamonds of unknown affinity from Bellsbank. One third of the diamonds from the Dan Carl Mine at Bellsbank reported by Deines (1980) have $\delta^{13} \mathrm{C}$ values in the range -2 to $-3 \%$.

Graphites from mantle eclogites thus appear to have an overall $\delta^{13} \mathrm{C}$ distribution similar to eclogite-suite diamonds. In both suites there is a strong peak near $-6 \%$, with a significant number of samples at lower and higher values, although the relatively few graphites do not define as wide a range of $\delta^{13} \mathrm{C}$ values as does the larger eclogitic diamond population.

The origin of the isotopically light and heavy eclogitic diamonds is controversial. Considered in isolation, the range of $\delta^{13} \mathrm{C}$ values for both eclogitic diamonds and graphites could be explained by several different processes. These include precipitation of native carbon from $\mathrm{CO}_{2}$ and $\mathrm{CH}_{4}$ vapours through Rayleigh fractionation, isotopic inhomogeneity in the mantle remaining since the accretion of the Earth, and subduction 
of oceanic basalt containing crustal biogenic and carbonate carbon (e.g., Deines, 1980; Kirkley and Gurney, 1989). Only the subduction hypothesis, however, adequately accounts for many of the other characteristics of mantle eclogites, characteristics such as positive Eu anomalies and anomalously high and low $\delta^{18} \mathrm{O}$ and $\delta^{34} \mathrm{~S}$ values, that defy explanation in terms of mantle igneous processes.

We suggest that the anomalous $\delta^{13} \mathrm{C}$ values for graphite in mantle eclogites support the subduction hypothesis. Furthermore, the model of Helmstaedt and Schulze (1989) of the formation of the subcratonic lithosphere by tectonic emplacement of ocean-floor material beneath the cratons can be extended to include even the shallow portion of the lithosphere represented by rocks from the graphite stability field.

Table 1. Carbon isotope composition of graphite from mantle eclogites, analyzed at the University of Wisconsin.

Location

Letlhakane

Jagersfontein

Bellsbank

Orapa

$$
\text { Sample }
$$

JSL-200

JSL-201

JSL-202

JSL-204

JSL-206

JSL-207

JSL-208

K7/555

K64/124

K64/128

K64/129

K64/133

K64/134

K64/147

K64/149

K64/169

K1/399

$\mathrm{K} 1 / 400$

K1/401

K1/402

K1/403

K1/404

K1/406 $\delta^{13} C_{\text {PDB }}$

$-5.54$

$-5.37$

$-7.68$

$-12.50$

$-5.68, \quad-5.75$

$-5.98$

$-5.90$

$-2.94$

$-5.69$

$-7.04$

$-2.95$

$-2.84$

$-5.38$

$-4.96$

$-5.47$

$-6.55$

$-6.19$

$-6.23$

$-4.64,-4.71$

$-5.67$

$-6.29$

$-6.00$ 


\section{REFERENCES}

Deines, P., Harris, J.W., Robinson, D.N., Gurney, J.J., and Shee, S.R. (1991) Carbon and oxygen isotope variations in diamond and graphite eclogites from Orapa, Botswana, and the nitrogen content of their diamonds. Geochimica et Cosmochimica Acta, 55, 515-524.

Deines, P., Harris, J.W., and Gurney, J.J. (1987) Carbon isotopic composition, nitrogen content and inclusion composition of diamonds from the Roberts Victor kimberlite, South Africa. Geochimica et Cosmochimica Acta, 51, 1227-1243.

Deines, P. (1980) The isotopic composition of diamonds: Relationship to diamond shape, color, occurrence and vapor composition. Geochimica et Cosmochimica Acta, 44, 943-961.

Harris, J.W. (1987) Recent physical, chemical, and isotopic research of diamond. In P.H. Nixon, Ed., Mantle xenoliths, p.477-500. Wiley, London.

Helmstaedt, H., and Schulze, D.J. (1989) South African kimberlites and their mantle sample - Implications for Archean tectonics and lithosphere evolution. In J.Ross, Ed., Kimberlites and related rocks Volume II: Their composition, occurrence, origin and emplacement, p.358-368. Blackwell, Carlton, Australia.

Kirkley, M.B., and Gurney, J.J. (1989) Carbon isotope modelling of biogenic origins for carbon in eclogitic diamonds. 28th International Geological Congress, Workshop on Diamonds, Extended Abstracts, 40-43.

Kropotova, O.I., and Fedorenko, B.V. (1970) Carbon isotope composition of diamond and graphite from eclogite. Geokhimiya, 10, 1279 (in Russian).

Pearson, D.G., Boyd, F.R., and Nixon, P.H. (1990) Graphite-bearing mantle xenoliths from the Kaapvaal Craton: Implications for graphite and diamond genesis. Annual Report of the Director of the Geophysical Laboratory, 1989-1990, 11-19.

Schulze, D.J., and Valley, J.W. (in press) Carbon isotope composition of mantle graphite: Anomalously light carbon subducted into the shallow subcontinental lithosphere (abs.) Geological Association of Canada/Mineralogical Association of Canada Annual Meeting, Toronto, May, 1991.

Sobolev, N.V., Galimov, E.M., Ivanovskaya, I.N., and Yefimova, E.S. (1979) The carbon isotope compositions of diamonds containing crystallographic inclusions. Doklady Academii Nauk SSSR, 249, 1217-1220.

Valley, J.W., and O'Neil, J.R. (1981) ${ }^{13} \mathrm{C} /{ }^{12} \mathrm{C}$ exchange between calcite and graphite: A possible thermometer in Grenville marbles. Geochimica et Cosmochimica Acta, 45, 411 419. 